\title{
Erratum to: Contamination assessment of ecotoxic metals in recent sediments from the Ergene River, Turkey
}

\author{
E. Sari ${ }^{1} \cdot$ N. Cukrov $^{2}$ (I) S. Frančišković-Bilinski ${ }^{2} \cdot$ M. A. Kurt ${ }^{3} \cdot$ M. Hallı $^{4}$
}

Published online: 6 January 2017

(C) Springer-Verlag Berlin Heidelberg 2017

\section{Erratum to: Environ Earth Sci (2016) 75:1051 \\ DOI 10.1007/s12665-016-5855-3}

In the original publication, author first name and the last name were interchanged. The correct version of author names is given below:

E. Sari, N. Cukrov, S. Frančišković-Bilinski, M. A. Kurt, M. Hallı doi:10.1007/s12665-016-5855-3.

\footnotetext{
N. Cukrov

ncukrov@irb.hr

1 Institute of Marine Science and Management, Istanbul University, 34134 Istanbul, Turkey

2 Division for Marine and Environmental Research, Institute "Ruđer Bošković", Bijenička 54, 10002 Zagreb, Croatia

3 Department of Environmental Engineering, Faculty of Engineering, Mersin University, 33358 Mersin, Turkey

4 Ethnography and Archeology Museum, 22020 Edirne, Turkey
} 